\title{
Comparative Evaluation on Performance of Copper and Stainless Steel Metal Freeze Branding in Sahiwal Cattle
}

\author{
Arvind K. Nandanwar ${ }^{1 *}$, Neelmani Kerketta ${ }^{2}$ and Sharad Mishra ${ }^{3}$ \\ ${ }^{1}$ SMS, KVK, Dhamtari, IGKV, Raipur (C.G.)-492012, India \\ ${ }^{2}$ AP, College of Agriculture, IGKV, Raipur (C.G.)-492012, India \\ ${ }^{3}$ ILFC, College of Veterinary Sciences and Animal Husbandry, CGKV, Anjora, \\ Durg (C.G.)-491001, India \\ *Corresponding author
}

\begin{abstract}
A B S T R A C T
\section{Keywords}

Stainless steel,

Copper, Freeze

branding, Exposure

time, Age group,

Sahiwal cattle,

Legibility of white

hairs, Scoring system.

Article Info

Accepted:

24 September 2017

Available Online:

10 November 2017

The present investigation was conducted at the Bull Mother Experimental Farm, College of Veterinary Science \& A.H., Anjora, Durg. Age group of Sahiwal cattle 0 to 6 and 6 to 12 months, the days required for appearance of white hairs was relatively lesser (43.33 \pm 1.20 and $42.8 \pm 4.93$ days) at 7 and 8 seconds, respectively for copper metal during freeze branding. In $12-18$ months of age group, minimum days (49.8 \pm 7.15$)$ required for appearance of white hairs were seen at 18 seconds of exposure time using stainless steel metal. Age group of 0 to 6,6 to 12 and 12 to 18 months, the 100 percent legibility of white hairs was seen mostly for stainless steel metal. The weak legibility of white hairs was seen in above 18 months of age group which can be attributed to the thickness of skin of animals which may have become thicker with advancement of age. Stainless steel metal was better than copper metal as 7.5 per cent animals scored 5 . Hence, it was concluded that stainless steel metal is better for all age group over copper metal. The mean value of neutrophils, before and after freeze branding, was $20.28 \pm 1.62$ and $22.62 \pm 2.47 \%$, respectively within the normal range and could not be an indication of stress associated with freeze branding.
\end{abstract}

\section{Introduction}

Identification of animal in livestock enterprise is of immense importance to draw conclusion of their status in production as well as performance. In Indian subcontinent, a huge amount of money has been spent to improve the dairy breeds; however, the achievements are still meagre. One possible reason for the failure could be attributed to poor adoption of scientific/best identification procedure considering the conduciveness to monitor the breed improvement programme in field condition. In rural area each and every family rear small livestock enterprises to meet out their family requirements, may be able to distinguish his animals by sight, by markings on animals. The large livestock enterprises would however, assess the herdsman memory to impuissance point. Marking of cattle for identification should involve methods that are easy to read at a distance, easy to apply, permanent, durable and economic. Several methods can be used to identify the animals. Out of that ear notching, ear tags and tattoos cannot be read without catching the head of 
animal (Hall et al., 2004). Beside this hot branding is widely practiced in organized and unorganized herds of India. This method has been strictly condemned by the society for prevention of cruelty against animals. There are several methods in vogue to identify the animal though none of them is flawless and foolproof (Mishra et al., 2005). Freeze branding offers a permanent form of identification i.e. easy to read at a greater distance, cause minimal damage to the hide and is less painful than hot branding (Lay et al., 1992 and Schwartzkopf-Genswein et al., 1997). This method resulted in destruction of pigment cells resulting in a white haired patch on the skin of Sahiwal. The Sahiwal is one of the best dairy breeds in India. The colour of Sahiwal is red. The white hair appearing on the skin will be permanent and remain easily readable. The present study was designed to observe the best exposure time of copper and stainless steel metal for effectiveness of freeze branding.

\section{Materials and Methods}

Present study was conducted on 80 Sahiwal cattle of different age groups at the Bull Mother Experimental Farm, College of Veterinary Science \& A.H., Anjora, Durg. Each group comprised of 20 animals (Table 1). The age of animals ranged from 0 month to above 18 months (Hall et al., 2004). The branding metal (copper and stainless steel) is an important instrument which acts as a medium to expose the required temperature to the skin of animals whereas, by various workers (Farrell et al., 1966 and Whitter et al.,1993) assessed copper metal but present studies on freeze branding comparison with stainless steel metal. The shape of metal was moulded to "I" shape and the width and depth (face to back) of metal brand are same for all age group of animals whereas length and weight was different on the basis of age group of animals (Bath et al., 1981). The liquid nitrogen was used as refrigerant. The temperature of it is nearly to $-196^{\circ} \mathrm{C}$ and remains as liquid in that temperature (Key et al., 1977 and Wagner et al., 2000). The frosted branding metal was quickly applied on the skin of the cattle with firm pressure by holding the metal on the area and do not let it slip.

Freeze branding experiment conducted mostly on exotic breed but there is no evidence for the indigenous breed i.e. Sahiwal, as well as no evidence of exposure time for freeze branding in Sahiwal, so we observe appearance of white hairs, legibility of white hairs, scoring system (Table 2) for selection of metal at different exposure times for different age groups (Farrell and Potter, 1966; Hall et al., 2004; Hooven et al., 1971 and McMahon et al., 2006) and also observe the stress by haematological parameter. To see the effectiveness of branding by different exposure times in different age groups one way analysis of variance was applied (Snedecor and Cochran, 1994) and any significant difference exist in any group then DMRT was applied (Steel and Torrie, 1984).

\section{Results and Discussion}

\section{Appearance of white hairs}

In 0-6 months age group, the average time for appearance of white hairs on the skin was found to be $45.6 \pm 1.96$ and $46.63 \pm 1.97$ days for copper and stainless steel metals, respectively (Table 3 ). The minimum and maximum time being $43.33 \pm 1.20$ and $50.5 \pm 2.10$ days, respectively. Relatively, lesser time was seen for the appearance of white hairs at 7 to 9 seconds $(43.33 \pm 1.20$ and $43.4 \pm 4.26$ days respectively) using copper metal. However all the values were nonsignificantly different with respect to both metals and exposure times. Similar results were found by Sherwin et al., (2002). 
In 6-12 months category an average time of $48.33 \pm 2.46$ and $46.78 \pm 1.96$ days, respectively for copper and stainless steel metal were observed for appearance of white hairs on skin following freezing (Table 3). The minimum and maximum days required for appearance of white hairs were $42.8 \pm 4.93$ and $58 \pm 2.08$ days, respectively. However, these results were in agreement with the findings of Bath et al., (1981) and Bertram et al., (2006), where they observe 6 weeks for the appearance of white hairs growth.

In Sahiwal, the average time for appearance of white hairs on skin were $58.09 \pm 1.34$ and $54.9 \pm 3.87$ days, respectively for copper and stainless steel metal with minimum and maximum days being $49.8 \pm 7.15$ and $62 \pm 00$ days, respectively in 12-18 months category (Table 3). In this age group, minimum of 49.8 \pm 7.15 days required for appearance of white hairs were seen at 18 seconds of exposure time using stainless steel metal. However, all the values did not differ significantly with respect to all exposure times and metals. Similar findings were observed by Bath et al., (1981) and Bertram et al., (2006).

Above 18 months of age group, the average time of appearance of white hairs on skin were $58 \pm 2.32$ and $56.77 \pm 3.82$ days, respectively for copper and stainless steel metal (Table 3). However, the minimum and maximum values for appearance of white hairs varied from $46.5 \pm 15.5$ to $63.5 \pm 3.5$ days for both types of metal. The difference in the time required for appearance of white hairs in all exposure time of copper and stainless steel metals were non-significant.

These findings were in accordance with the findings of Sherwin et al., (2002). Overall, a trend was noticed that relatively more days were required for appearance of white hairs with the advancement of age.

\section{Legibility of white hairs}

In 0-6 month's category, the legibility of white hairs for copper metal varies from 60 to 100 percent. For stainless steel metal the legibility varies from 40 to 100 percent in spite of non-significant difference $\left(\chi^{2}=5.064\right)$ among them (Table 4). However, the chisquare value indicated non-significant difference between the legibility of white hairs and various exposure times. Although 100 per cent legibility was observed in 9 and 7 seconds of exposure time using copper and stainless steel metal, respectively. The 80 per cent legibility was seen at 5 and 9 seconds of exposure time in stainless steel metal is also acceptable. In 6-12 months of age group, the legibility of white hairs for copper metal varied from 60 to 100 percent. In case of stainless steel, the legibility varied from 40 to 100 percent, in spite of this no significant difference $\left(\chi^{2}=4.758\right)$ among them was noticed (Table 5). In copper metal, the chisquare value $\left(\chi^{2}=2.932\right)$ indicated nonsignificant difference between legibility of white hairs with respect to their exposure time. The copper metal has given 80 to 100 percent result at 11 to 8 seconds of exposure time. Similar results were observed in stainless steel metal where 80 to 100 per cent legible white hairs were observed at 11 to 8 seconds of exposure time.

The chi-square values were 0.601 and 8.8 for copper and stainless steel metal, respectively in 12-18 months category. Overall the minimum and maximum value of frequency (in percentage) of legible white hairs varied from 20 to 100 percent in both metal. In copper metal, the legible white hairs appeared less than 80 percent and were non-significant $\left(\chi^{2}=0.601\right)$. Whereas in stainless steel, the legibility varied from 20 to 100 percent in spite of having significant difference $\left(\chi^{2}=8.8\right)$ between for all the exposure time (Table 6). 
Table.1 Different exposure time proposed for different age group

\begin{tabular}{|c|c|c|c|}
\hline Age (months) & \multicolumn{2}{|l|}{ No. of Animal } & Exposure time (seconds) \\
\hline \multirow{3}{*}{$0-6$} & \multirow{3}{*}{20} & 5 & 5 \\
\cline { 3 - 4 } & & 5 & 7 \\
\cline { 3 - 4 } & & 5 & 9 \\
\cline { 3 - 4 } & \multirow{3}{*}{20} & 5 & 8 \\
\hline \multirow{3}{*}{$6-12$} & 5 & 5 & 11 \\
\hline & & 5 & 14 \\
\hline & \multirow{3}{*}{$12-18$} & 5 & 17 \\
\hline & \multirow{3}{*}{20} & 5 & 12 \\
\hline & & 5 & 15 \\
\hline & & 5 & 18 \\
\hline & \multirow{3}{*}{20} & 5 & 21 \\
\hline & & 5 & 17 \\
\hline & & 5 & 20 \\
\hline & & 5 & 23 \\
\hline & & 5 & 26 \\
\hline
\end{tabular}

Table.2 The scoring system

\begin{tabular}{|c|c|}
\hline Score & Interpretation \\
\hline 1 & No visible numbers \\
\hline 2 & Visible numbers, but illegible. \\
\hline 3 & Incomplete numbers, but able to understand. \\
\hline 4 & Easily recognizable numbers, but with breaks or unbranded areas. \\
\hline 5 & Instantly recognizable, complete unbroken numbers. \\
\hline
\end{tabular}

Table.3 Mean time for appearance of white hairs using various metals of same dimension in a given exposure time for Sahiwal cattle

\begin{tabular}{|c|c|c|c|}
\hline $\begin{array}{c}\text { Age Group } \\
\text { (month) }\end{array}$ & $\begin{array}{c}\text { Exposure Time } \\
\text { (Seconds) }\end{array}$ & \multicolumn{2}{|c|}{ Appearance of white hairs (days) } \\
\cline { 2 - 4 } & 5 & Copper & Stainless steel \\
\hline \multirow{4}{*}{$0-6$} & 7 & $45 \pm 6.35$ & $44.75 \pm 3.79$ \\
\cline { 2 - 4 } & 9 & $43.33 \pm 1.20$ & $47.6 \pm 3.33$ \\
\cline { 2 - 4 } & 11 & $43.4 \pm 4.26$ & $45.75 \pm 5.57$ \\
\hline \multirow{4}{*}{$6-12$} & 8 & $50.5 \pm 2.10$ & $49.50 \pm 2.50$ \\
\cline { 2 - 4 } & 11 & $42.8 \pm 4.93$ & $45.6 \pm 5.03$ \\
\cline { 2 - 4 } & 14 & $46.75 \pm 5.02$ & $45.5 \pm 3.18$ \\
\cline { 2 - 4 } & 17 & $50 \pm 1.15$ & $48 \pm 2.08$ \\
\hline \multirow{4}{*}{$12-18$} & 12 & $58 \pm 2.08$ & $50.5 \pm 1.50$ \\
\cline { 2 - 4 } & 15 & $57.66 \pm 1.45$ & $58 \pm 0.00$ \\
\cline { 2 - 4 } & 18 & $60 \pm 2.00$ & $60 \pm 3.06$ \\
\cline { 2 - 4 } & 21 & $58 \pm 4.73$ & $49.8 \pm 7.15$ \\
\hline \multirow{4}{*}{ Above 18 } & 17 & $57.33 \pm 2.33$ & $62 \pm 00$ \\
\cline { 2 - 4 } & 20 & $63.5 \pm 3.5$ & $46.5 \pm 15.5$ \\
\cline { 2 - 4 } & 23 & $52.33 \pm 2.03$ & $53.5 \pm 1.5$ \\
\cline { 2 - 4 } & 26 & $62 \pm 00$ & $62.66 \pm 1.45$ \\
\hline
\end{tabular}


Table.4 Mean value of frequency (in percentage) of legible white hairs on the animals in 0 to 6 months age group of Sahiwal cattle

\begin{tabular}{|c|c|c|}
\hline \multirow{2}{*}{$\begin{array}{c}\text { Exposure Time } \\
\text { (Seconds) }\end{array}$} & Frequency of legible white hairs (percentage) \\
\cline { 2 - 3 } & Copper $(\boldsymbol{\%})$ & Stainless steel (\%) \\
\hline 5 & 60 & 80 \\
\hline 7 & 60 & 100 \\
\hline 9 & 100 & 80 \\
\hline 11 & 80 & 40 \\
\hline Chi square & 2.932 & 5.064 \\
\hline
\end{tabular}

Table.5 Mean value of frequency (in percentage) of legible white hairs on the animals in 6 to 12 months age group of Sahiwal cattle

\begin{tabular}{|c|c|c|}
\hline \multirow{2}{*}{$\begin{array}{c}\text { Exposure Time } \\
\text { (Seconds) }\end{array}$} & \multicolumn{2}{|c|}{ Frequency of legible white hairs (percentage) } \\
\cline { 2 - 3 } Copper $(\boldsymbol{\%})$ & Stainless steel $\mathbf{( \% )}$ \\
\hline 8 & 100 & 100 \\
\hline 11 & 80 & 80 \\
\hline 14 & 60 & 60 \\
\hline 17 & 60 & 40 \\
\hline Chi square & 2.932 & 4.758 \\
\hline
\end{tabular}

Table.6 Mean value of frequency (in percentage) of legible white hairs on the animals in 12 to 18 months age group of Sahiwal cattle

\begin{tabular}{|c|c|c|}
\hline \multirow{2}{*}{$\begin{array}{l}\text { Exposure Time } \\
\text { (Seconds) }\end{array}$} & \multicolumn{2}{|c|}{ Frequency of legible white hairs (percentage) } \\
\cline { 2 - 3 } & Copper (\%) & Stainless steel (\%) \\
\hline 12 & 60 & 20 \\
\hline 15 & 40 & 60 \\
\hline 18 & 60 & 100 \\
\hline 21 & 60 & 20 \\
\hline Chi square & 0.601 & $8.8^{*}$ \\
\hline
\end{tabular}

Values superscripted by different letters differed significantly from each other in a column $* \mathrm{P}<0.05$

Table.7 Mean value of frequency (in percentage) of legible white hairs on the animals in above 18 months age group of Sahiwal cattle

\begin{tabular}{|c|c|c|}
\hline \multirow{2}{*}{$\begin{array}{c}\text { Exposure Time } \\
\text { (Seconds) }\end{array}$} & \multicolumn{2}{|c|}{ Frequency of legible white hairs (percentage) } \\
\cline { 2 - 3 } Copper (\%) & Stainless steel (\%) \\
\hline 17 & 40 & 40 \\
\hline 20 & 60 & 40 \\
\hline 23 & 20 & 60 \\
\hline 26 & 20 & 40 \\
\hline Chi square & 2.414 & 0.601 \\
\hline
\end{tabular}


Table. 8 Scores and percentage of animals for both metals

\begin{tabular}{|c|c|c|c|}
\hline \multirow{2}{*}{$\begin{array}{l}\text { Age Group } \\
\text { (month) }\end{array}$} & \multirow[t]{2}{*}{ Score point } & \multicolumn{2}{|c|}{ Frequency (in percentage) of animals in different metals } \\
\hline & & Copper & Stainless steel \\
\hline \multirow{5}{*}{0 - 6} & 1 & 20 & 25 \\
\hline & 2 & 15 & 10 \\
\hline & 3 & 25 & 20 \\
\hline & 4 & 25 & 15 \\
\hline & 5 & 15 & 25 \\
\hline \multirow{5}{*}{$6-12$} & 1 & 25 & 30 \\
\hline & 2 & 15 & 10 \\
\hline & 3 & 45 & 35 \\
\hline & 4 & 15 & 20 \\
\hline & 5 & - & 5 \\
\hline \multirow{5}{*}{$12-18$} & 1 & 45 & 50 \\
\hline & 2 & 20 & 10 \\
\hline & 3 & 25 & 35 \\
\hline & 4 & 10 & 5 \\
\hline & 5 & - & - \\
\hline \multirow{5}{*}{ Above 18} & 1 & 65 & 55 \\
\hline & 2 & 15 & 25 \\
\hline & 3 & 15 & 15 \\
\hline & 4 & 5 & 5 \\
\hline & 5 & 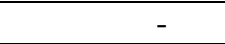 & - \\
\hline
\end{tabular}

Table.9 Overall classification of all the animals (in percentage) on the basis of score points for copper and stainless steel metal

\begin{tabular}{|c|c|c|}
\hline \multirow{2}{*}{ Score point } & \multicolumn{2}{|c|}{ Metal } \\
\cline { 2 - 3 } & Copper & Stainless steel \\
\hline $\mathbf{1}$ & 38.75 & 41.25 \\
\hline $\mathbf{2}$ & 16.25 & 13.75 \\
\hline $\mathbf{3}$ & 27.50 & 26.25 \\
\hline $\mathbf{4}$ & 13.75 & 11.25 \\
\hline $\mathbf{5}$ & 3.75 & 7.5 \\
\hline
\end{tabular}

Table.10 Mean \pm SE change in Haematological parameters before and after freeze branding in Sahiwal

\begin{tabular}{|c|c|c|c|c|}
\hline S.No. & Haematological Parameter & Before branding & After branding & Significans \\
\hline 1. & $\mathrm{TEC}\left(10^{6} / \mu \mathrm{l}\right)$ & $6.53 \pm 0.33$ & $6.54 \pm 0.22$ & $\mathrm{NS}$ \\
\hline 2. & $\mathrm{Hb}(\mathrm{gm} \%)$ & $8.62 \pm 0.53$ & $8.40 \pm 0.44$ & $\mathrm{NS}$ \\
\hline 3. & $\mathrm{PCV}(\%)$ & $28.20 \pm 2.0$ & $28.60 \pm 1.0$ & $\mathrm{NS}$ \\
\hline 4. & $\mathrm{TLC}\left(10^{3} / \mu \mathrm{l}\right)$ & $5.71 \pm 0.45$ & $8.25 \pm 0.6$ & $\mathrm{NS}$ \\
\hline 5. & Neutrophils & $20.28 \pm 1.62$ & $22.62 \pm 2.47$ & $* *$ \\
\hline 6. & Lymphocytes & $57.42 \pm 2.83$ & $59.54 \pm 2.40$ & $*$ \\
\hline 7. & Monocytes & $6.26 \pm 0.52$ & $6.42 \pm 0.73$ & $*$ \\
\hline 8. & Eosinophils & $10.58 \pm 0.99$ & $11.06 \pm 0.80$ & $\mathrm{NS}$ \\
\hline 9. & Basophils & $0.12 \pm 0.10$ & $0.22 \pm 0.13$ & $* *$ \\
\hline
\end{tabular}

Values superscripted by different letters differed significantly from each other in a column $* \mathrm{P}<0.05 * * \mathrm{P}<0.01 \mathrm{NS}=$ non-significant 
Fig.1 Frequencies (in percentage) for scores of white hairs for copper and stainless metal

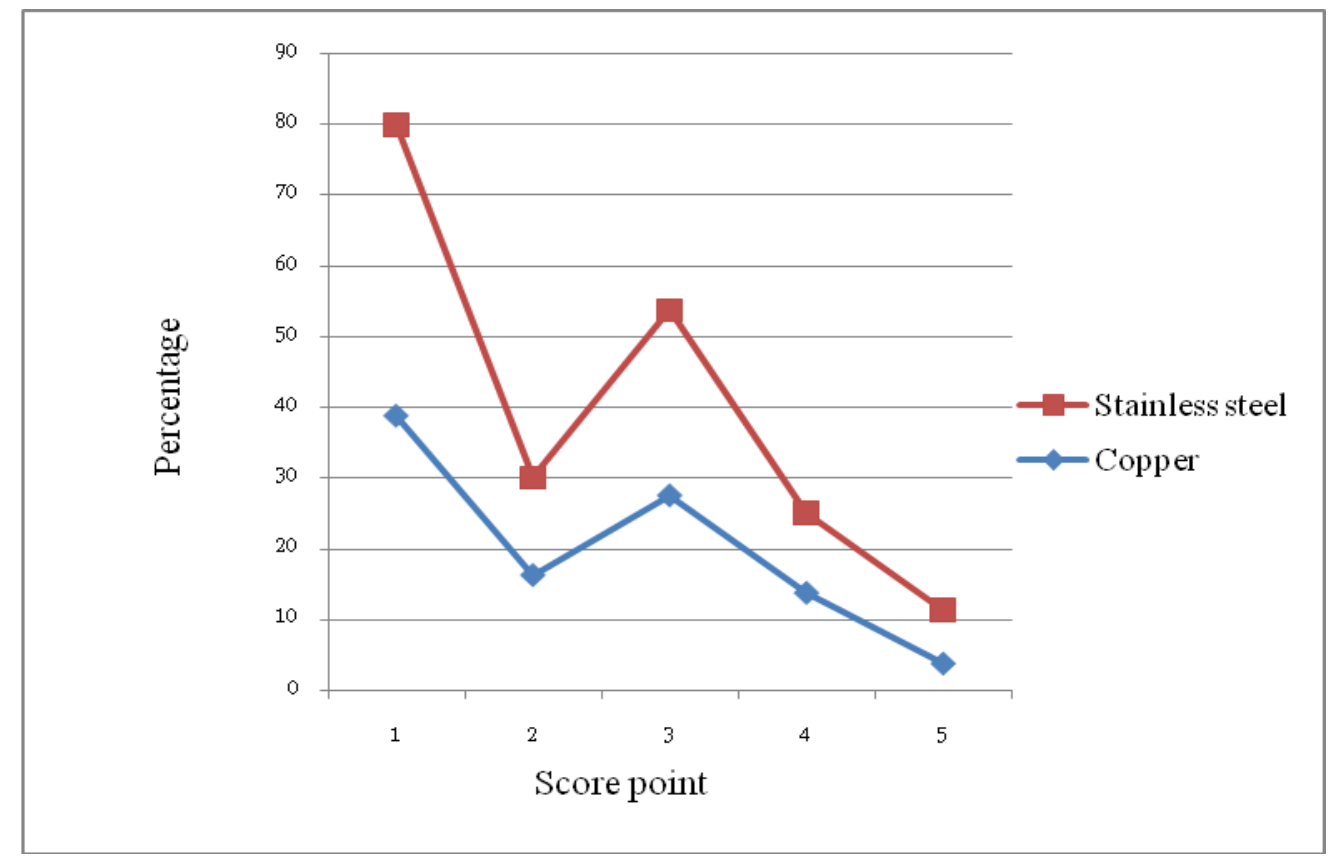

Above 18 months of age group, the chi square values were 2.414 and 0.601 respectively for copper and stainless steel metal. Overall minimum and maximum frequency (in percentage) of animals for white hairs varied from 20 to 60 percent in both metals (Table 7). The chi square values indicated nonsignificant difference with respect to all the exposure time. In spite of this, the appearance of white hairs was less than 80 percent; hence, legibility may be ambiguous after 18 months of age.

\section{Selection of metal}

In case of score 3, 4 and 5 the developed white brand was for copper (25, 25 and $15 \%$ animals, respectively) and for stainless steel $(20,15$ and $25 \%$ animals, respectively) in $0-6$ months category. At score 5 maximum percentage of instantly recognizable number was observed in stainless steel metal (25 percent) followed by copper metal (15 percent) (Table 8). These findings are in agreement with the results reported earlier by Thrift et al., 1971.
In 6-12 months of age group 25, 15, 45 and 15 percent animals had scored 1, 2, 3 and 4, respectively for copper metal. However, maximum percentage (45 percent) of animals scored 3 (Table 8 ). In case of stainless steel metal 30, 10, 35, 20 and 5 percent animals, respectively scored 1, 2, 3, 4 and 5. Maximum percentage (35 percent) of animals scored 3 and after score 3 marked reduction in visible white hairs was observed in 4 and 5 scores, as these scores are known for better visibility of white hairs. Interestingly, stainless steel metal was the only metal which scored 5 .

In 12-18 months category copper metal (45, 20,25 and $10 \%$ animals) and stainless steel metal (50, 10, 35 and 5\% animals) had score of $1,2,3$ and 4 , respectively (Table 8).

Overall, 10 percent animals contained visible hairs, when copper metal was used, which is higher that of stainless steel (5 percent) considering score 3 and 4 higher visibility was noticed in stainless steel metal than that of copper metals. However, differences among metals were non-significant. 
The scores 1, 2, 3 and 4 were $65,15,15$ and 5 percent, respectively for copper metal, whereas decline trend of improvement in visibility of white brand with increase in score points was noticed in above 18 month (Table 8 ). None of the animals branded with copper scored 5. Similar trend was noticed in stainless steel metal. However, differences among metals were non-significant.

Irrespective of exposure times and age groups, all the animals were classified according to the score points of 1, 2, 3, 4 and 5 for both metals studied in present investigation (Table 9 and Figure 1).

Further stainless steel metal, 25 and 5 percent animals scored 5 at 0 to 6 months and 6 to 12 months age group, respectively. However, overall efficiency of stainless steel metal was better than copper as 7.5 percent animals scored 5.

\section{Haematological parameter}

The mean value of neutrophils, before and after freeze branding, were $20.28 \pm 1.62$ and $22.62 \pm 2.47$ percent, respectively and the difference between them was highly significant $(\mathrm{P}<0.01)$ in response of body defence mechanism (Barragry, 1994). The mean value of lymphocytes $(57.42 \pm 2.83$ and $59.54 \pm 2.40$ per cent), monocytes $6.26 \pm 0.52$ and $6.42 \pm 0.73$ percent) and basophils $(0.12 \pm 0.10$ and $0.22 \pm 0.13$ percent $)$ were before and after freeze branding, respectively (Table 10).

Overall, age group of 0 to 6 and 6 to 12 months, the number of days required for appearance of white hairs was relatively lesser ( $43.33 \pm 1.20$ and $42.8 \pm 4.93$ days) at 7 and 8 seconds, respectively for copper metal. In 12 to 18 months of age group, minimum days (49.8 \pm 7.15$)$ required for appearance of white hairs were seen at 18 seconds of exposure time using stainless steel metal. The differences in the time required for appearance of white hairs in all exposure time of above 18 months age groups of copper and stainless steel metal were non-significant.

Overall, age group of 0 to 6,6 to 12 and 12 to 18 months, the 100 percent legibility was seen in exposure time 7 (for stainless steel) and 9 (for copper), 8 (for both metals) and 18 (for stainless steel) seconds of exposure time, respectively. Therefore, stainless steel metal could be recommended. The weak legibility of white hairs was seen in above 18 months of age group which can be attributed to the thickness of skin of animals which may have become thicker with advancement of age (Hamid et al., 2000). Perhaps increase in weight of metals could have given better legibility of white hairs.

Overall efficiency of stainless steel metal was better than copper metal as 7.5 per cent animals scored 5. Hence, it was concluded that stainless steel metal is better. Farrell (1967) and Torell et al., (2001) who observed that copper to be more efficiently use with more success than brass, steel and aluminium. But in present investigation, stainless steel metal could give better results.

The lymphocytes and monocytes have showed significant rise $(\mathrm{P}<0.05)$ whereas, neutrophils and basophils were also increased significantly $(\mathrm{P}<0.01)$, but above results were within the normal range and could not be an indication of stress associated with freeze branding.

\section{Acknowledgments}

I humbly extend my profound gratitude to my Professors and staff, college of Veterinary science and AH, CGKV, Durg for their constant support and valuable suggestions offered during the course of research work. 


\section{References}

Barragry, T.B. 1994. Veterinary Drug Therapy. Lea and Febiger, Philadelphia, pp 59-60.

Bath, D., Dickinson, F. and Appleman, R.H.A. 1981. Dairy Cattle Principles, Practices, Problems, Profits. $3{ }^{\text {rd }}$ Edition. K. M. Varghese Company, pp. 416-418.

Bertram, J., Gill, B. and Coventry, J. 2006. Freeze branding. Agnote Animal Production, alice Springs J., 15: 1-5.

Farrell, R.K. 1967. Freeze branding as an International Animal Identification System. Washington Farmer.

Farrell, R.K., Koger, L.M. and Winward, L.D. 1966. Freeze branding of cattle, dogs and cats for identification. J. Am. Vet. Med. Assoc., 149: 745-752.

Hall, J.B., Greiner, S.P. and Gregg, C. 2004. 'Cattle identification: Freeze branding'.,400-301.

Hamid, M.A., Husain, S.M.I., Khan, M.K.I., Islam, M.N. and Biswas, M.A.A. 2000. Skin thickness in relation to milk production of crossbred cows. Pakistan J. Biological Sci., 3(9): 1525-1529.

Hooven, N.W.Jr. and Hollon, B.F. 1971. Freeze branding on unclipped areas. J. Dairy Sci., 54(5): 785(Abstr.).

Keys, J.E., Hooven, N.W., Weinland, B.T. and Miller, R.H. 1977. Effect of anatomical site, exposure time, age, refrigerant and breed on legibility of freeze marks on dairy cattle. $J$. Dairy Sci., 60(7): 1163-1168.

Lay, D.C., Friend, T.H., Randel, R.D., Bowers, C.L., Grissom, K.K. and Genkins, O.C. 1992. Behavioral and physiological effects of freeze or hot iron branding in crossbred cattle. J. Anim. Sci., 70: 330-336.

McMahon, C.R., Burton, H.R., VanDenHoff, J., Woods, R. and Bradshaw, C.J. 2006.
Assessing hot-iron and cryo-branding for permanently marking southern elephant seals. J. wildl. Management, 70: 14841489.

Mishra, S., Roy, S., Bhonsle, D. and Chourasia, S.K. 2005. Determination of exposure time for freeze branding in sahiwal breed. $J$. Agri.,10(1): 13-19.

Potter, G. 1966. Branding and The leather industry. Proc. Freeze Brand Seminar, Washington State University.

Schwartzkopf-Genswein, K.S., Stookey, J.M., and Welford, R. 1997. Behavior of cattle during hot iron and freeze branding and the effects on subsequent handling ease. J. Anim. Sci., 75: 2064-2072.

Sherwin, R.E., Haymond, S., Stricklan, D. and Olsen, R. 2002. Freeze branding to permanently mark bats. Wildlife Society Bulletin, 30(1): 97-100.

Snedecor, G.W. and Cochran, W.G. 1994. Statistical methods. $8^{\text {th }}$ edition. Iowa State University Press, Iowa, USA.

Steel, R.G.D. and Torrie, J.H. 1984. Principles and procedures of statistics, A Biometrical approach. $2^{\text {nd }}$ edition. McGraw - Hill International Book Company.

Thrift, F.A. and Absher, C.W. 1971. Freeze branding versus fire branding as methods of beef cattle identification. J. Range Manage., 24(1): 75-78.

Torell, R., and Riggs, W.N. 2001. Freeze Branding Ranch Animals. University of Nevada Cooperative Extension, Fact Sheet 01-25.

Wagner, R.W., Helmondoller, R., and Pritchard, J. 2000. Beef cattle. Extension Service. West Virginia University.

Whittier, J.C. and Ross, E.J. 1993. Agricultural publication GO2202-Reviewed.

\section{How to cite this article:}

Arvind K. Nandanwar, Neelmani Kerketta and Sharad Mishra. 2017. Comparative Evaluation on Performance of Copper and Stainless Steel Metal Freeze Branding in Sahiwal Cattle. Int.J.Curr.Microbiol.App.Sci. 6(11): 3130-3138. doi: https://doi.org/10.20546/ijcmas.2017.611.367 